DOI: $10.20472 / B M C .2018 .008 .015$

\begin{abstract}
HANA SLOVÁČKOVÁ
Mendel University in Brno, Faculty of Forestry and Wood Technology, Department of Forest and Wood Products Economics and Policy, Czech Republic
\end{abstract}

\title{
PAVEL KLEIN
}

Mendel University in Brno, Faculty of Forestry and Wood Technology, Department of Forest and Wood Products Economics and Policy, Czech Republic

\section{JAKUB MICHAL}

Mendel University in Brno, Faculty of Forestry and Wood Technology, Department of Forest and Wood Products Economics and Policy, Czech Republic

\section{DAVID BŘEZINA}

Mendel University in Brno, Faculty of Forestry and Wood Technology, Department of Forest and Wood Products Economics and Policy, Czech Republic

\section{BUSINESS ETHICS AND CORPORATE SOCIAL RESPONSIBILITY AS A TOOL TO STIMULATE INTEREST IN THE LIVING ENVIRONMENT}

\begin{abstract}
:
Business ethics, corporate social responsibility and environmental management in business largely overlap and are often the reason for the controversy over their effectiveness and real benefits for businesses and society. An elementary prerequisite for their effective functioning is the overall social interest. Specifically, it concerns the interest on the part of businesses management and, on the other hand, the interest of the citizens who are able to appreciate these practices and put a special emphasis on them. The constant pressure for the protection of the environment from interest groups and international organizations is of a fundamental importance in the development and application of ethical, social and environmental standards that are used in business practice. The information contained in this article presents the information from both primary and secondary surveys carried out in the Czech Republic. The aim of the information is to assess the attitudes of the respondents in the Czech Republic toward the issue of the overall social nature, which the business ethics and related areas such as corporate social responsibility and environmental management certainly are. In the light of the results of national surveys, it is possible to talk about a contradictory perception of these areas. The contradictory nature can be mainly seen in the positive attitudes toward the acquaintance with this issue and the real interest in the support through a financial compensation of such an approach to business. All interpretations are based on the data, which are derived from the questionnaire surveys carried out in the years 2015 - 2018.
\end{abstract}

\section{Keywords:}

social responsibility, marketing, forest products, labor and consumers, labor management, environmental and ecological economics, sustainable development

JEL Classification: M14, Q00, Q01 


\section{Introduction}

In the context of ethics, ethics in business is not a whole new discipline. However, it is true that in recent years in our country and in other developed countries, an increasingly larger space and attention are being dedicated to it (Nečadová, 2014). In terms of historical development, the application of ethical principles in business activities comes from the USA where the business ethics between 1900 and 1950 was almost exclusively an American affair. Since the early 1950s, it has also penetrated into Europe where the interest in this issue has increased considerably (Luknič, 1994). The theoretical basis of business ethics is the link between general ethics and general economics (Nečadová, 2014).

If one focuses on the situation in the Czech Republic, the development and the creation of business ethics is bound to the period of capitalism in the country. (Nečadová, 2014) It can be seen that 1990s are, above all, characterized by the search for the essential background and assumptions of business ethics (business ethics - BE) and corporate social responsibility (corporate social responsibility - CSR), (Čaník, Čaníková, 2006).

Post-communist countries such as the Czech Republic, however, unfortunately do not have a positive reputation in the world when it comes to ethical standards and corruption. Business ethics, therefore, became one of the factors that foreign companies consider when entering the market in Central Europe or the Czech Republic (Šípková, Choi, 2015). Čaník and Čaníková (2006) claim that among the European economies, the Czech Republic is generally seen as being less ethical than the old EU Member States (e.g. France, Germany, etc.), but more ethical than other new Member States (e.g. Poland or Hungary).

Since the recovery of the market economy in 1989 in the Czech Republic, Czech companies as well as Government officials have started to find out that business ethics is an important factor affecting the overall quality and the international attractiveness of the local business environment. They have also retrieved the importance of the anti-corruption measures, corporate social responsibility of businesses, and business ethics (Šípková, Choi, 2015). In the Czech Republic, however, the situation in the perception of business ethics is changing only slowly. When it comes to the compliance with the general standards of economic ethics, perhaps the greatest discontent can be seen in the area of fulfilment of commitments and payment ethics (Friedel, 2003).

With the knowledge of their primary and completely natural aim (i.e. maximizing their profits), companies in the Czech Republic are developing a variety of other activities. Outside the support of various socially responsible activities, some of the companies are trying to implement different ethical instruments (codes of ethics, etc.). Despite that, there still is not a sufficient amount and quality of information about practical tools of BE and CSR and their comprehensive implementation - this insufficiency is mainly notable in small and medium-sized businesses (Čaník, Čaníková, 2006).

In business ethics, it is by far not just a matter of "image", but increasingly a matter of the economic necessity, which has a direct impact on business results. The responsibility of a company's access to their surroundings and the environment is one of the assessment 
criteria of companies and their values. It affects the decision-making of investors, customers, business partners and the overall impression, which the general public shapes about the company (Friedel, 2003).

The gradual development of globalization is responsible for the global growth in trade. This development definitely helped a lot of companies to become global players. However, globalization also has the other side of the coin, that manufacturers and growers from the third world countries do not have such options to compete with multinational corporations in the world markets. The struggle between these small local producers and large companies can literally be described as unfair. And also because of that, organizations trying to set up a fair trade with its set rules and principles are being formed. In that way, they are trying to give developing countries a chance for a decent work with the goal of prosperity.

With regard to the relatively high interest in this issue in recent years, the number of nongovernmental organizations and associations dedicated to popularization, counseling, training and evaluation of results, at national level particularly, is increasing. Besides the Czech Board of Quality of the Czech Republic, there are other subjects involved in the promotion and spreading the awareness of corporate social responsibility and promotion of the CSR in the Czech Republic, such as Association of corporate social responsibility, Business Leaders Forum, Business for society, Czech Business Council for Sustainable Development, AISIS, CG Partners, and Global Compact Network Czechia. In the case of business ethics, these are organizations such as the Ethical Forum of the Czech Republic, Transparency International, Association of Fair Business, and many other organizations.

The relationship between business ethics, corporate social responsibility and environmental management is rooted in the environmental ethics. All of the aspects that form the basis of the functioning of these business tools for sustainability carry elements of environmental ethics.

Environmental ethics in itself involves the relationship between man and other non-human beings as well as the relationship to non-living nature. It suggests how one should deal with the world and nature, which is understood as one's own environment. It is trying to get us closer to the deeper meaning of life on Earth, and at the same time wants to show us another perception of a human's place in nature. It points to the way of life, which we should not only lead but, above all, want to realize. It tells us "what we must know and how we should act with regard to the ecological dimension of our being" (Vladyková, 2009).

The whole definition is based on the essence of the indispensable need to act in accordance with the preservation of the world and nature and to create values with regard to the ecological dimension of our being. This addition also carries business activity within itself.

The fact that current trends in management and practice put an ever-greater emphasis on socially responsible business activity is also evidenced by the fact that ever since the 1980 s, sustainable development has been considered as the only possible scenario of further development of human society. Sustainability consists of a change in the approach 
to the use of natural resources, the restriction of the negative impact on the natural environment (e.g. the excessive production of waste and pollution) and the economic and social balance of the development of all cultures and social groups (Koubská and Hralová, 2006).

In common business practice, there are several interesting forms of applying business ethics, corporate social responsibility and environmental management at the same time. One of them is a certification. If we build on the general definition of the word certificate, it is a is a verification, a confirmation or a license. Legally, it is a written official verification or certification. A certificate credibly confirms the relation between the subject's identity and its properties.

In relation to the business management, it specifies the basic system requirements in organizations, which want and need to demonstrate their ability to provide products / services in line with applicable regulations and customer requirements, and which seek to increase customer satisfaction. In connection with the environmental and societal interests, it is even a tool of sustainability that ensures the preservation of nature and landscape for future generations. Often it not only solves current problems but as well eliminates the occurrence of problems in the future.

A Fair Trade certificate can be mentioned as a concrete example of certification that combines corporate social responsibility, ethical conduct, and also takes into account the long-term sustainable environment.

The motto of the fair trade is very simple: people deserve to get well and fairly paid for their work. Fair trade is a way of trade that provides farmers, employees and craftsmen from the countries of the global South (developing countries) with the opportunity to earn one's living with their own work under decent conditions (Fair Trade CR/SR, 2018).

The idea of fair trade, however, is not only based on ethical conduct in business. Another very important component is a sustainable living environment. It means that one should not act according to a motto "there can be a flood after us", but approach the environment gently, with care, ethically. Fair trade farmers strive for long term sustainable production and do not use agrochemicals as a precautionary measure, but only in the case of being confronted by pests or diseases. Ultimately, we, as final customers and consumers, can act with social responsibility and with our purchases of products labeled as Fair Trade help those who need it the most - usually people from the third world countries (Nečadová, 2014).

Another suitable example of a project that is closely related to business ethics and corporate social responsibility is FSC and PEFC certification.

This certification is ideologically perceived as a voluntary mechanism that has emerged due to concerns about sustainable management of forest resources. The main purpose of this certification is to confirm that the action taken on a particular forest area meets the standards set by third party organizations. However, opinions of different subjects on the certification vary considerably when it comes to the question of economic impacts of this voluntary mechanism (Vlosky et al., 2015). 
The aim of the contribution is to assess the actual effectiveness of the selected types of certification as a tool to stimulate interest in activities related to business ethics and corporate social responsibility. Another partial objective is to evaluate the real interest in the societal environmental problems of the environmental character from the position of consumers, and to mediate the results of primary and secondary research in this field.

\section{Material and Methods}

The information processed in this paper comes from primary and secondary data from the national surveys conducted in the Czech Republic. The findings in the literary research are a selection of available domestic and foreign sources of articles, books and publications available on the web. Based on the processed data, it is possible to partially outline the situation of the Czech Republic in the issue of corporate social responsibility and business ethics. On the basis of the primary surveys, it is also possible to state what the actual effectiveness and benefits of the certification systems oriented at the mentioned areas are. In the case of marketing tools oriented at the motivation toward the environmental interest, it concerns mainly the environmental objectives and sustainability choices of supporting products that are produced in accordance with the environmentally-friendly principles. These steps lead a number of subjects towards the appreciation of such business activities and thus provide a motivation stimulus in the company that should raise interest in an increasing number of manufacturing as well as non-manufacturing businesses.

The issue of sustainability and social responsibility is definitely interlinked and also results in the increase in people's interest in protecting the landscape and the environment. It is also evidenced by the fact that the area where respondents in the CR (Czech Republic) are the most engaged is the protection the environment. $91 \%$ of the population sorts waste, and at the same time, $51 \%$ has actively been recycling in the past year and more than one third of the respondents prefers organic products.

Given the fact that in 2015 , only $79 \%$ of the surveyed sample sorted waste, it is also possible to speak of a rising trend, as the interest of consumers is very high and increases every year.

According to the survey the focus of companies on environmental protection and related areas, such as social responsibility or ethics in business, is a key marketing option for addressing consumers.

According to the current "IPSOS CSR \& REPUTATION RESEARCH 2016" survey, up to $35 \%$ of the population of the Czech Republic spontaneously recalls a specific organization dedicated to social responsibility. This evoked a significant increase compared to previous years, where it was only $24 \%$ (the survey was carried out on sample of $n=1009$ respondents). Therefore, according to this survey, social responsibility plays an important role in the consumer behavior as well as in the choice of an employer (NIP, 2017).

In 2016, there was a survey carried out by the authors Michal and Sujová (2017) in the Czech Republic with the aim to evaluate the consumer opinion of the FSC and PEFC certification. The consumer questionnaire was focused on the behavioral analysis in the 
case of the preference of products whose production is a subject to the criteria of sustainability and socially responsible behavior of business entities (the survey was carried out on a sample of $n=404$ respondents).

The authors of the article conducted a further research for obtaining the primary data. This was a questionnaire survey on the territory of the Czech Republic, whose aim was to evaluate the consumer's perception on the Fair Trade certification specifically. Data collection took place in the period between the 23rd and 27th of July, primarily electronically, partially physically. The questionnaire survey has been carried out on a sample of $n=320$ respondents.

The basic prerequisite for the correctness of the output data was the definition of the exact sample size of respondents in the working age of the respective country (Czech Republic) to maintain the value of the research investigation. The sample size of respondents carried out by authors of the survey included a statistically significant value of the total population size of the Czech Republic in the working age. In the case of the calculation of a representative sample of respondents and the subsequent determination of the minimum number for the acceptance of the questionnaire survey, the figure for the population in the working age from 2015 (CZSO), specifically 6997 700, was used. The working age group of respondents ranged from 15 to 64 years of age, which was also the target group for data collection from the questionnaire survey (i.e. the questionnaire almost exclusively addressed the respondents in this age group). The percentage of error was set to $5 \%$ as the standard statistically used value.

Such surveys also provide important insights and indicate the direction, which should be taken in a long-term business strategy. It is also essential to monitor each branch in which such principles play an important role, whether in terms of direct or indirect benefit.

\section{Attitudes of consumers in the CSR area}

The outputs of IPSOS CSR \& REPUTATION RESEARCH 2016 also mention that $68 \%$ of respondents were willing to pay more for a green product, see (Figure 1), and these figures are also equal with the primary data by the author from 2017 , when almost $87 \%$ of respondents stated that they would be willing to pay a "premium price" for a timber product with added value. 
Figure 1: Preferences of the social responsibility of the respondents in the Czech Republic

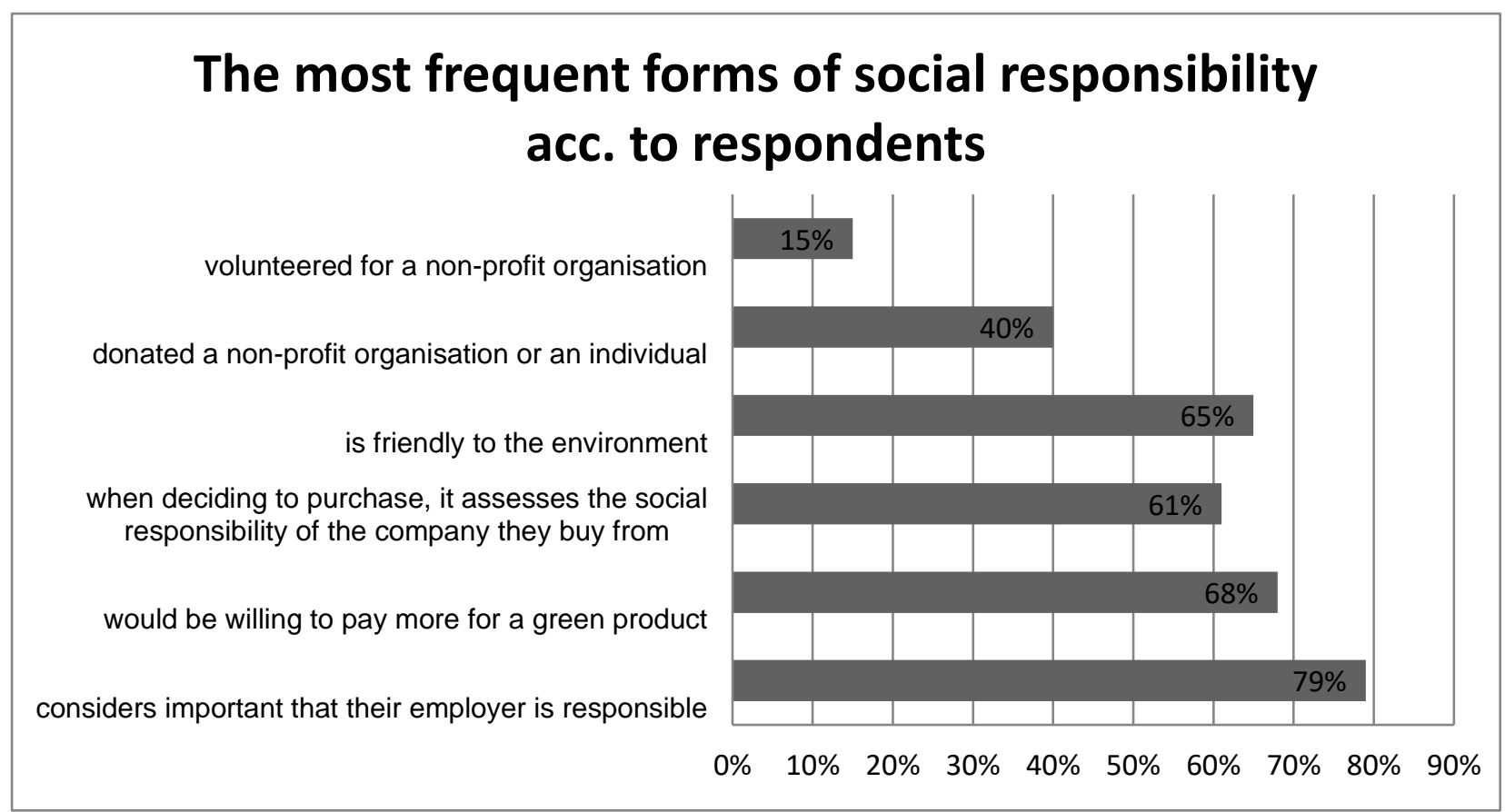

Source: Own elaboration based on the IPSOS CSR \& REPUTATION RESEARCH 2016

As can be seen from the foregoing facts, social responsibility in the Czech Republic has a wide range of applications and also ordinary citizens without the expertise of this issue are interested in it. In connection with these statements, it is also worth mentioning the fact that, according to the survey, the vast majority of Czechs $(90 \%)$ are in some way responsible and 2/3 say they behave ecologically. IPSOS's results are compared in the next part with research surveys on consumer perceptions and the socio-economic impact of different types of certificates whose philosophy is based on corporate social responsibility, business ethics and nature conservation.

\section{The History of Fair Trade}

The creation of fair trade dates back to the 1940s and 1950s, when the society with the development of globalization, and therefore of trade, started to perceive the need for it. The first mentions can be seen in the Church organizations, which imported handicraft goods from the producers in the developing countries. In that way, two organizations were formed - SERRV and Ten Thousand Village (SERRV - a non-profit organization with a mission to eradicate poverty supporting farmers and craftsmen around the world) and TenThousand (a company dealing with the import, distribution and sale of handicraft goods from the countries of the third world) (TenThousandvillages, 2018).

These organizations stood behind the creation of the organization and certification Fair Trade. Its establishment is dated by the year 1964. The United Nations (UN) signed up for a new perspective on the development aid, with their main motto being "Trade not aid". This motto began to control the organization, which declared that it favors trade - or 
market solutions before a one-time financial aid provided to the given country. Five years later, in 1969, the first store concerned with selling exclusively Fair Trade products purchased directly from the craftsmen from the third world countries was established.

As each company or an organization is affected by the economic cycles, the Fair Trade certification also registered certain complication in the 1980s. Stock market crash resulted in the decline of trade concerning small craftsmen and producers in the developing countries. The result was that in 1986, Mexican coffee farmers have approached a nongovernmental organization with the request to support the sale of their production (Audebrand, Pauchard, 2009).

Together, they subsequently created a system of labelling products, which at that time was a completely revolutionary step. Two years later, in the Netherlands, the first Fair Trade brand was established - Max Havelaar. Products bearing this label warned their buyers that the product is being treated on the basis of specific rules, principles and policies. The market reacted to this new labelling positively and the products with this label experienced a great popularity with customers. This label began to spread, and started to be used to a greater extent (TradeFairTrade, 2010).

The best known and most widely used products, which carry the label of the Fair Trade certification include coffee, tea, chocolate, cereals and fruit. Other food products labeled as Fair Trade include a variety of beverages and spices, sweeteners, etc. This certification is used, of course, by the manufacturers and producers of non-food products as well. These include natural cosmetics, fashion accessories, toys, etc. (Raynolds, 2007).

\section{Fair Trade}

The FINE organization formulated the following definition of the Fair Trade certification:

"Fair Trade is a trading partnership based on a dialogue, transparency and respect, and which aims at greater justice in the international trade. It contributes to sustainable development by offering better trading conditions and protects the rights of small producers and farmers - especially in the developing countries. Fair Trade organizations (backed by the consumers) actively support the producer as well as the awareness and promote changes in the rules and ways of conventional international trade." (Fridell, 2007)

The international organization FINN4, which has long been trying to make the Fair Trade certification more visible has established several major objectives in this area:

- Improvement of the living conditions of the manufacturers and producers through a fairer market approach

- Strengthening of the primary producers with more favorable purchase prices in the business partnership

- Supporting the development opportunities of the beneficiary producers, especially women and traditional peoples and the protection of children from abuse in the production process 
- Raising awareness among the end customers about the negative impact of international trade on producers, so that they can use their purchase power positively

- Creating a sample example of a business relationship through dialogue, mutual respect and transparency

- Organizing campaigns for a change in the rules and practices of conventional international trade

- Protection of human rights through the promotion of social justice, environmental protection and economic security (Landivar, 2004)

Zásady Fair Trade:

- Business partnership

- High-quality and environmentally friendly products

- Control and transparency

- Having a choice

- Emphasis on high-quality information

- The correct information (Marcovitz, 2011)

\section{Fair Trade as an artificial construct}

We can, of course, also find a considerable sample of consumers who are against the Fair Trade certification. As the Financial Times journalists found on the plantations in Peru, the workers of Fair Trade producers of certain products were receiving a higher wage as opposed to the producers that do not have this certification, however, even these wages were still lower than the statutory minimum wage in the given state. However, this was not the only finding of the journalists. Furthermore, they discovered that one producer labeled as Fair Trade even illegally grew about $20 \%$ of their production in the protected nature reserve. For the Fair Trade certification, this is as unacceptable as the child labor on the plantations. What results from this is that in the long term the Fair Trade certification helps particular countries, however, at the same time it enabled the existence of illegal activities, whether in the form of illegal trade or other infringements. In other words, it can be concluded that the certification does not guarantee everything, and that the people who decide how the certification and the production will be treated continue to be an important factor. (Fajmon, 2010)

\section{Fair Trade in Czech Republic}

Company promoting fair trade in the Czech Republic was established in 2003. Behind its establishment, there is a group of students who wanted to start promoting these products on the territory of the Czech Republic so that they could be commonly purchased here. At 
the beginning of the cooperation, however, the Czech company also had to accept the main standards and ideas of Fair Trade, which are:

1. Fair price - One of the first points that the certification of Fair Trade is built on is fair price, which every craftsman and farmer deserves for their performed work.

2. Community development - When there is a company supporting Fair Trade cooperation being established, it also creates new trade unions, whose main task is the promotion of social development and the environment.

3. Nature protection - Other main aims of Fair Trade organizations include the protection of the environment. In this case, the vast majority of farmers cannot use any chemicals or other preparations leading to the promotion of the cultivation.

4. Long-term business relations - The Fair Trade movement ensures a long-term cooperation with the producers. Thus, the craftsmen and farmers immediately know what the financial evaluation will be, and especially when they will get paid for the work.

5. Dignified working conditions - The Fair Trade organization guarantees working hours for a given activity, appropriate working conditions, and overall a pleasant working environment.

6. Equal rights - In the countries of the third world, one also often sees the inequality of rights. In many of the countries, women are being discriminated and have almost no rights. Within the framework of the Fair Trade certification, this fact is being fought against.

7. Demokracie - The one who decides to collaborate with Fair Trade is actively involved in the mutual cooperation, future projects and most importantly, can be a part of important decision-making.

8. Prohibition of child labor - according to the Fair Trade movement, every child should have the right to education, which plays a constant and a very important role in every person's life and often decides about one's future development. (FairTrade, 2018).

\section{The impact of Fair Trade certification on product price}

As noted in the text above, products labeled with the Fair Trade certification have a positive economic impact on the marketability of the product itself.

In the context of this article, there was a short evaluation done of the difference in the prices of coffee with and without the Fair Trade identification. These prices were obtained from the supplier of coffee in Belgium. In the context of the comparison, it should be noted that the elementary and the main reason that influences the prize is the origin, processing, and, of course, the coffee yield. At the same time, it is also true that the purchase prices of green coffee range from EUR 2 to 50 per kilogram. Table 1 lists the coffees that are close to each other and can be compared thanks to the country of origin, the type of coffee and its processing, and last but not least the formal reviews of coffees. The evaluation, which was 
created and used since 1998, is based on the basis of tasting of the roasted coffee by trained tasters and filling in an already standardized SCA forms. This form contains the following core evaluation criteria:

- Lack of defects - coffee with any, even minor defects will most likely have reviews under 70 points. If a fault is detected, one may experience a decrease of points by 1 to 3.

- Sweetness - several kinds of sweet flavors, such as honey, sugar and fruit can be observed in the coffee. The more prominent and more pleasant sweet taste, the higher the score

- Acidity - even in regard to the acidic factor, one observes a total of three types, namely, apple, grape (wine acidity) or citric.

- Aftertaste - a bitter taste on the tongue which we observe in the last part of tasting. High ranking is attributed to a coffee that has the perfect balance between bitterness and sweetness.

- General taste - coffee has a slightly different viscosity. What is critical, however, is how consistent the coffee itself is.

- Flavor - coffee, which has the smell and taste specific for a certain type of fruit (peach, cherry, black currant, etc.) increases its rating. (Brown, 2018)

Table 1: Comparison of a coffee vendor's coffee prices - standard and Fair Trade

\begin{tabular}{|l|l|l|l|r|r|}
\hline Country & $\begin{array}{l}\text { Fair } \\
\text { Trade }\end{array}$ & Mark & Evaluation & Price & $\begin{array}{l}\text { Difference } \\
\text { in \% }\end{array}$ \\
\hline Ethiopia & NO & Limu grade 2 crop 2016/17 & $84+$ & $€ 3,88$ & \\
\hline Ethiopia & YES & Sidamo 2 | Fairtrade Organic 2017 & $84,5+$ & $€ 7,83$ & $102 \%$ \\
\hline Honduras & NO & SHG EP 2018 Organiccert & $84+$ & $€ 4,91$ & \\
\hline Honduras & YES & SHG EP 2018 | FairtradeOrganic & $83,5+$ & $€ 5,84$ & \multirow{2}{*}{$19 \%$} \\
\hline India & NO & Cherry AB & & $€ 2,96$ & \multirow{2}{*}{$60 \%$} \\
\hline India & YES & Cherry AB | Fairtrade Organic & & $€ 4,74$ & \multirow{2}{*}{$31 \%$} \\
\hline Brazil & NO & $\begin{array}{l}\text { NY2 17/18 ssfc -"DIAMOND" - } \\
\text { CROP 2017/18 }\end{array}$ & $82+$ & $€ 3,48$ & \\
\hline Brazil & YES & Sc14+ SS FC Fairtrade 2017/18 & $83+$ & $€ 4,57$ & \multirow{2}{*}{$31 \%$} \\
\hline
\end{tabular}

Source: Own adjustment based on the coffee supplier's pricelist 32CUP (internal document authors article)

- Coffee from Ethiopia has the largest difference in purchase prices. In principle, however, this is due to the region and the origin of coffee.

- In regard to coffee from Honduras, the difference is already more noticeable. Coffees are of the same designation and origin. The evaluation is different in only 0.5 point, while the coffee labeled as Fair Trade is about $19 \%$ more expensive. 
- Similarly, one can evaluate the coffee from India, which has the same designation. The difference in price here is $60 \%$

- This comparison closes with the coffee from Brazil. On the basis of experience, one can define that the coffees are very similar, which is also evidenced by their similar reviews. The difference in this case is $31 \%$

\section{Certification and the impact on the buyer}

As has already been explained from a theoretical standpoint and listed based on a practical example of the coffee, the certification has an impact on the selling price of the products. Fair Trade products are sold for more than the coffee without this certification.

What is important, however, is the perception of the end customers, which, shop for coffee, or any other product labeled as Fair Trade. KPMG has done an extensive research on the territory of the Czech Republic in April 2017, which was attended by 1000 respondents. A part of the research included two questions dedicated to the purchase of Fair Trade products. Specifically, it dealt with roasted coffee.

The first of the questions is: What part of all the coffee that you buy is coffee labeled as Fair Trade? The results are astounding - only $1 \%$ of the respondents said that they exclusively buy Fair Trade coffee. In sum, $12 \%$ of respondents buys fair-trade coffee on a regular basis. On the contrary, in sum, $70 \%$ of respondents have either never heard of the certification, or they do not buy coffee with this certification.

\section{Figure 2: KPMG - Fair Trade coffee still struggles with uninformation}

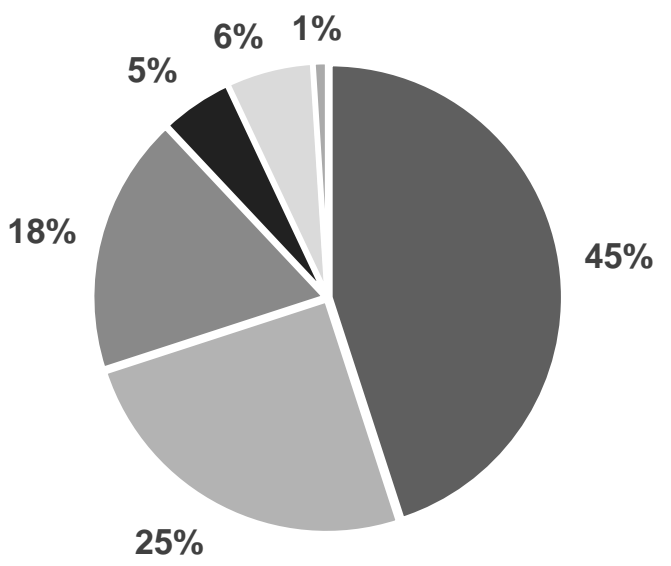

- I hear about this coffee certificate for the first time

- I don't buy Fair Trade coffee, but I know the Fair Trade certificate

- Sometimes I buy Fair Trade coffee, but most of the consumption is another coffee without certificate

- It accounts for about half of my coffee purchases

- I buy mainly Fair Trade coffee, but sometimes I buy another

- I buy exclusively Fair Trade coffee 
The second question deals with the comparison in the level of education of the respondents and its impact on the purchase of Fair Trade coffee. The results describe that knowledge of the Fair Trade certification is higher among people with university degrees $-75 \%$. Compared with the end-customers with a primary education, the awareness of the certification was noticed in $36 \%$ of the respondents.

\section{The results of our own Fair Trade certification research}

Following up on information obtained from the secondary data, we have prepared a questionnaire dealing with the awareness of a specific certification - Fair Trade. The questionnaire survey was attended by 320 respondents residing in the territory of the Czech Republic. Data collection took place mainly in the form of an electronic questionnaire, the older age groups of respondents attended via a written questionnaire, which was subsequently rewritten into the digital form. The questionnaire was attended by $79 \%$ of women and $21 \%$ of men. Age categories of respondents were as follows: $52 \%$ of respondents, i.e. the largest group of respondents, was of age between 18 and 28 years. In the range between 29 and 39 years, there was $28 \%$ of the respondents. The third largest of the represented groups consisted of persons in the age range between 40 and 50 years, who made up a total of $11 \%$. Respondents in the age range between 51 and 61 years made up $6 \%$ of the total. The last $3 \%$ were respondents with the age of 62 and more.

Other questions of identification included one about the highest educational level achieved by the respondents. A total of $51 \%$ of the respondents formed a group with university degrees. The second largest group consisted of respondents with high school education with graduation being the highest achieved, $37 \%$ of the total. The rest, i.e. $12 \%$, consisted of the respondents with a primary education, secondary education completed with a vocational certificate, and with higher education qualification.

The status of the respondents was as follows: one half of the respondents consisted of employees of state-owned or private companies. The questionnaire was attended by a total of $21 \%$ of students. There was an equal number of $12.5 \%$ both for the respondents who are entrepreneurs and the respondents on maternity leave. Similarly, an equal number of $2.1 \%$ was achieved both for the unemployed respondents, and old-age pensioners.

The most frequent gross monthly income of the respondents is between CZK 20,001 and 30,000 , for a total of $30 \%$ of the participants. $27 \%$ of the respondents said that their income is between CZK 10,001 and 20,000. A gross monthly income of CZK 10,000 and less was registered in $20 \%$ of the respondents, which is directly related to the status of these respondents - students. Respondents whose gross monthly income is between CZK 30,001 and 40,000, CZK 40,001 and 50,000, and CZK 50,001 and more make up a total of $24 \%$.

The first research question of the questionnaire survey was concerned with whether the respondents know or are aware of the Fair Trade certification. In sum, more than three quarters of the respondents said that they have a basic or detailed information about the certification. Specific results are listed in the chart below. 
Figure 3: Do you know the meaning of the Fair Trade certification?

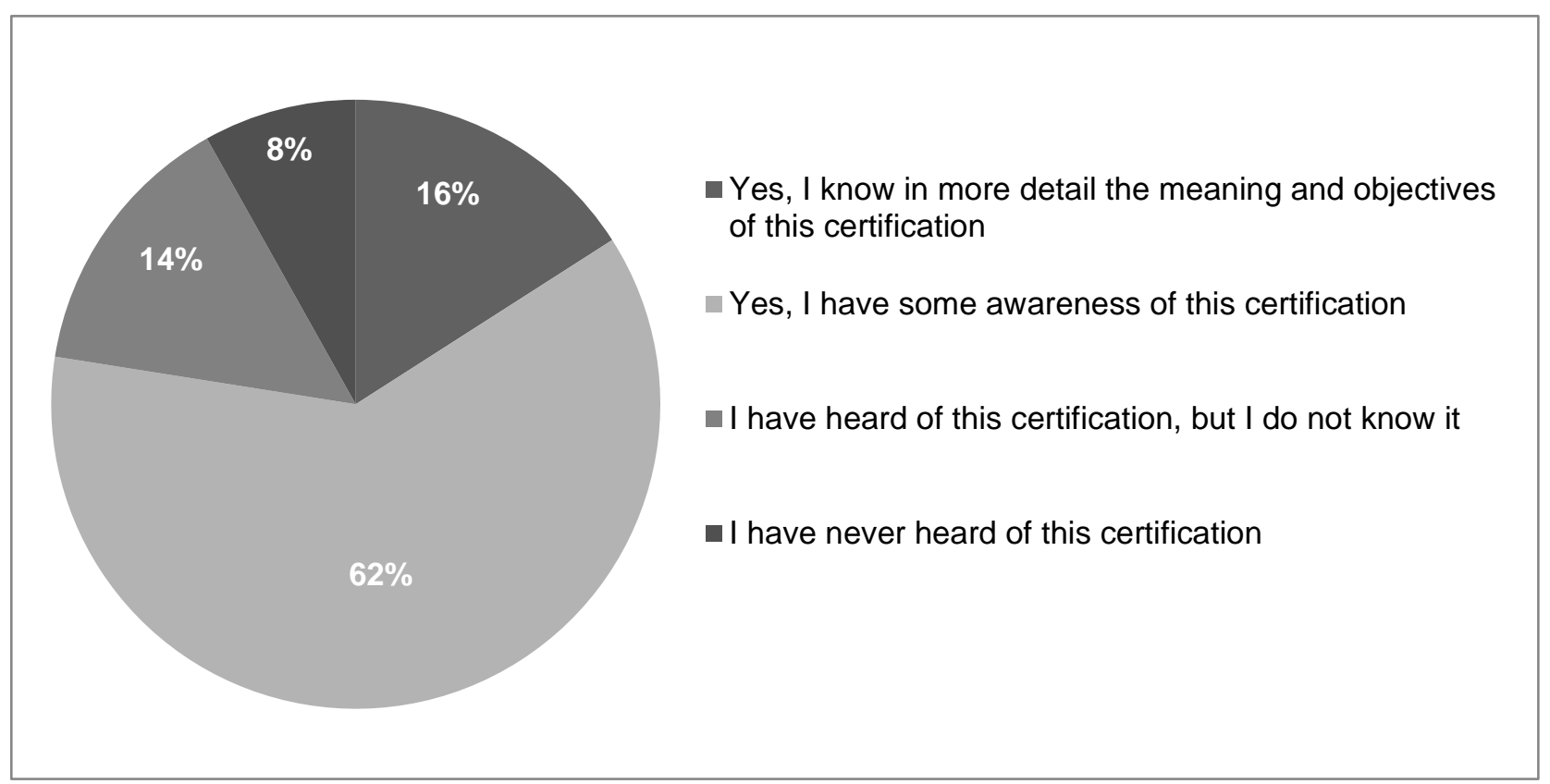

Source: Own adjustment (Fair Trade research, 2018)

Almost the same amount of respondents correctly identified the Fair Trade certification logo. This question presented a total of four logos of certification authorities, namely the Rainforest Alliance, the FSC and PEFC, and Fair Trade. $74 \%$ of the respondents correctly chose the logo of the Fair Trade company.

The previous two answers confirm the general awareness of the certification authorities such as Fair Trade, when the consumers often know the certification. In contrast, the previous as well as this questionnaire survey confirm that consumer decisions about purchasing products with the certification do not have such an effect. It is also confirmed by the following answers to the questionnaire question, namely, whether the respondents are buying products labeled as Fair Trade. Only one respondent out of 320 participating replied that they exclusively buy products labeled as Fair Trade. The most frequent answers of the respondents, a total of $49 \%$, state that a part of the products that they purchase consists of the those labeled as Fair Trade. An important sample consists of the remaining $51 \%$ of respondents who either do not seek products labeled as Fair Trade or are not aware of the fact that the products in their shopping cart were labeled with the certification. Detailed statistics are included in the chart below. 
Figure 4: Do you buy Fair Trade products?

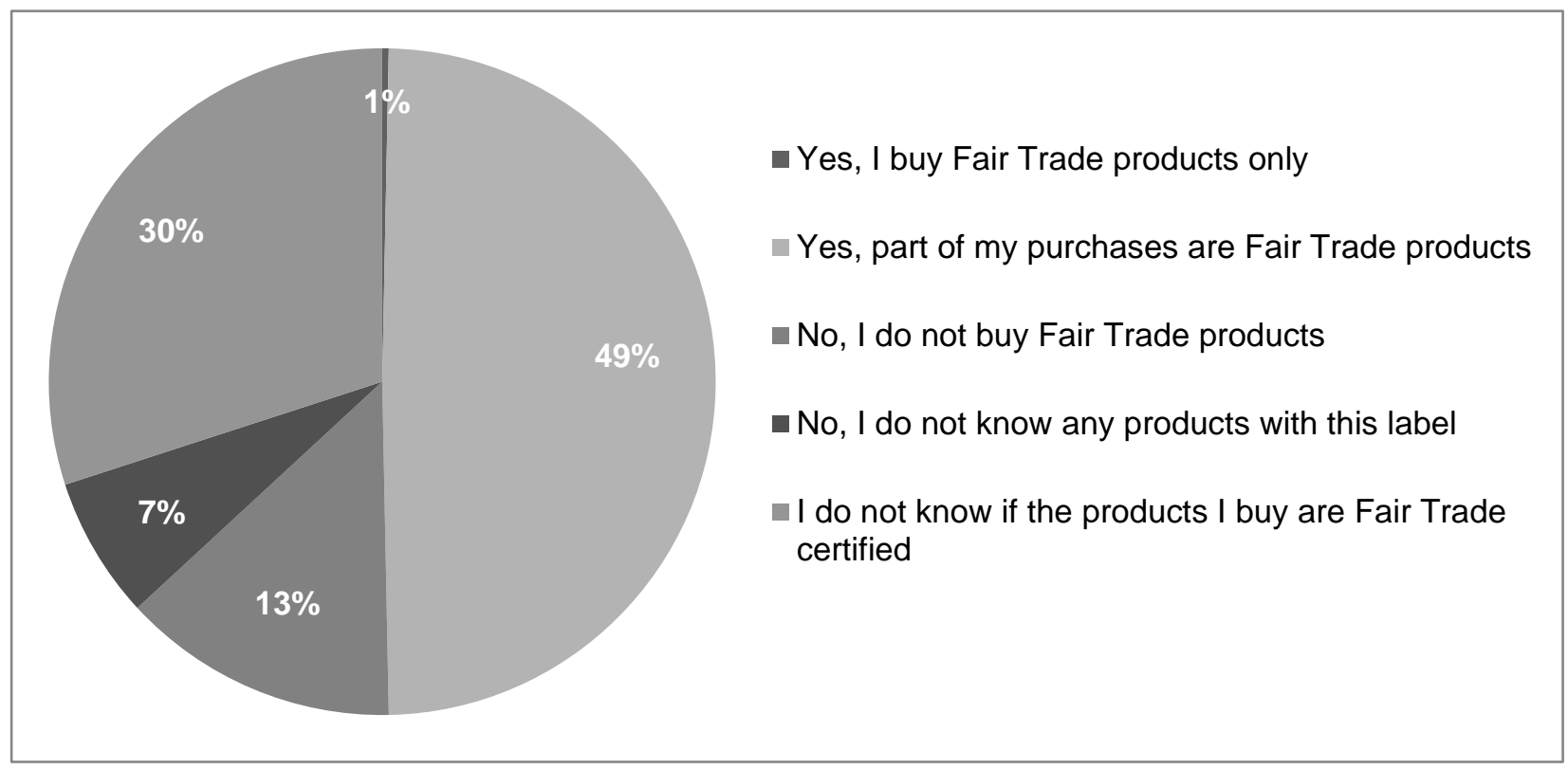

Source: Own adjustment (Fair Trade research, 2018)

Interesting information can also be derived from the answers to another research question asking whether and how much more the consumers are willing to pay for Fair Trade certified products. More than a quarter of the respondents, $27 \%$ specifically, would be willing to pay $20-40 \%$ on top of the usual price. The same number of responses was included by the respondents who do not purchase products labeled with the Fair Trade certification or do not know that the products in their shopping cart were labeled so.

The last research question was focused on the assessment of five primary factors affecting the consumer's purchase. These factors included: quality, price, discount, product labeled with a certification, and additional services. Averaged results are listed in the (Table 2) below. The assessment scale was in the range between 1 and 5 , with a value approaching 1 signifying the greatest impact on the consumers' shopping behavior. A value approaching 5 has the least impact on consumers' shopping behavior.

Table 1: Evaluate the relevance of individual criteria when purchasing products

\begin{tabular}{|l|r|}
\hline Quality & 1,33 \\
\hline Price & 2,24 \\
\hline Discount & 2,56 \\
\hline Certification & $\mathbf{2 , 9 1}$ \\
\hline Additional services & 3,36 \\
\hline
\end{tabular}

Source: Own adjustment (Fair Trade research, 2018)

The research indicates that the most important factors in the consumer's purchase are quality and price. The product labeled with a certification took the fourth place and obtained an average assessment of 2.91 points. 


\section{The results of the FSC and PEFC certification}

To assess the significance of the impact of certification on corporate social responsibility practices, business ethics and a sustainable renewable resource management systems, the results of the FSC and PEFC certification from 2017 were compared with the previous data.

To compare the data from previous researches, issues of the same / similar focus were selected in order to assess perceptions in different sectors.

Specific numbers clearly speak against the certification systems, where up to $82 \%$ of respondents could not identify the connection of the certification systems FSC and PEFC with the protection and preservation of nature. However, it is evident that it only concerns a perceptive ability to identify without any further characterization of the brand's properties, its connection with the environmental sector and the pursuit of the sustainability of forest ecosystems. The fact that many of the respondents also considered the names of businesses, state entities, civil associations, or the World Wide Fund for Nature as ecological labels is also paradoxical.

If the certification logos are known (Figure 5), the results of the survey show a very positive character, but in the control question, " Do you know what kind of logo (symbol) are labelled products made from wood material or wood in accordance with nature's conservation and protection?" only 83 respondents were able to indicate the appropriate certification markings correctly.

\section{Figure 5: Knowledge of certification marks FSC and PEFC (by logo)}

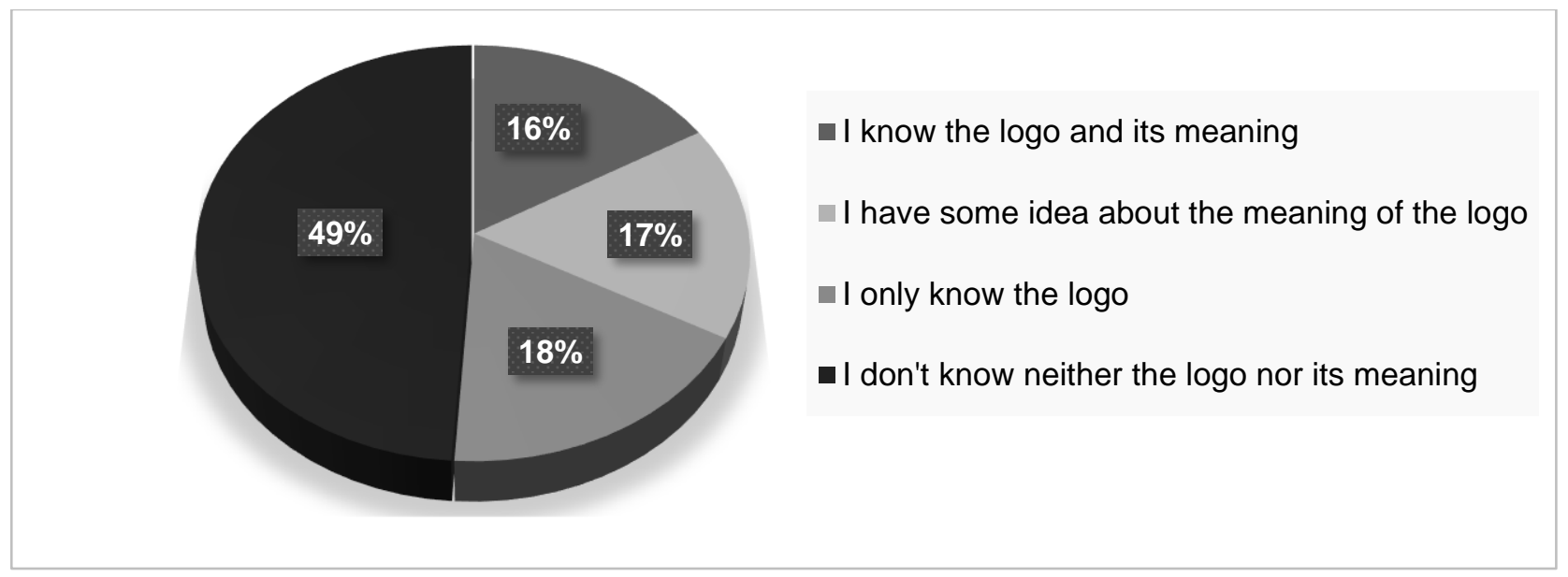

Source: Own adjustment based on the IGA_LDF_VP_2017003 research

From the results of IPSOS 2016 on the question: Which of the following areas would according to you support most companies in the Czech Republic as part of their corporate social responsibility?", $47 \%$ of respondents said they were fair behavior towards employees, equally important area was the protection of the environment with $46 \%$, and $24 \%$ said business ethics. 
Conformity of the above mentioned results can also be supported by another survey. (Figure 6), where the question: „If you were offered the opportunity to choose between a wood product (furniture, paper, wood, wood raw material, wooden house) that is more expensive but environmentally friendly, you prefer more expensive or cheaper without added value?" $45 \%$ of respondents said they prefer certified products that are related to environmental protection, ethical business in the context of EUTR (European timber trading regulation 2013) and social responsibility in the form of minimizing externalities.

\section{Figure 6: Attitudes of consumers to the preference of organic products}

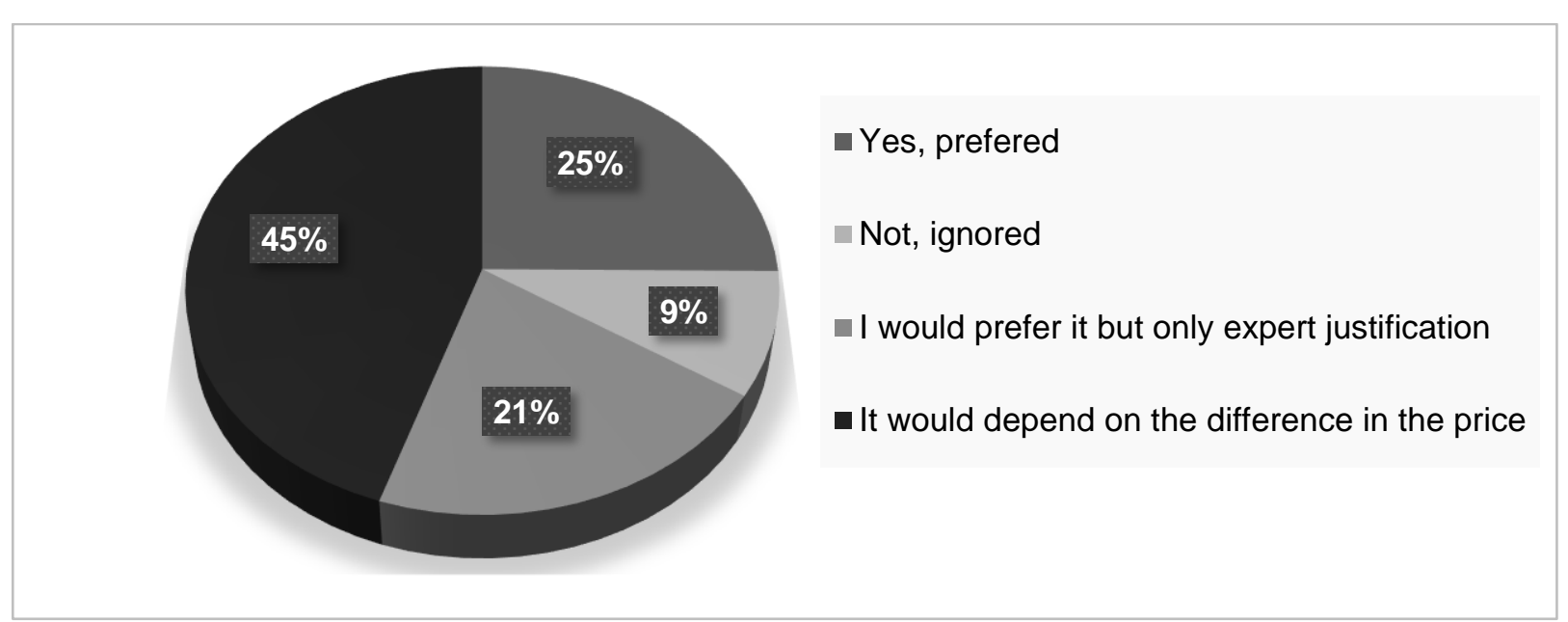

Source: Own adjustment based on the IGA_LDF_VP_2017003 research

As the saying goes "nice on paper, but the reality is different," so it is with the Czech consumer willingness to pay more for certified products with added value. Price and quality are a key factor in the real consumers buying behaviour. Social responsibility, business ethics and nature conservation resonates with companies as activities that are welcomed and should be encouraged, however, if these activities do not increase quality, but the cost, the interest of consumers is insignificant.

As in the case of the Fair Trade survey and as well the FSC and PEFC certification, the price and quality that can be seen in (Table 3) play the most important role in purchasing decisions. These figures are interesting in the context of CSR surveys and also by KPMG, where the vast majority of respondents showed interest in activities related to corporate social responsibility, environmental products and ethical business activities. Despite all the above mentioned facts, the price is still a decisive criterion and the above mentioned activities remain suppressed by the products price. 
Table 3: Evaluation of the primary criterion when choosing a purchased item.

\begin{tabular}{|l|r|}
\hline Price & $9,8 \%$ \\
\hline Quality & $14 \%$ \\
\hline Price/quality ratio & $68,5 \%$ \\
\hline Discount & $4,1 \%$ \\
\hline Expert advicing & $3,6 \%$ \\
\hline Additional services & $0 \%$ \\
\hline Source: Own elaboration based on the IGA LDF VP 2017003 research
\end{tabular}

Source: Own elaboration based on the IGA_LDF_VP_2017003 research

\section{Conclusion}

The perception of business ethics, corporate social responsibility and the relation to the environmental preservation can be considered as a positive increasing trend in the current population. These conclusions can be supported by the actual results of the surveys, but most of all, it is evidenced by the day-to-day media space devoted to such practices. Every small positive step that will lead to the reduction and then to a complete breakdown of externalities' creation is certainly a welcome step for today's society and, of course, for future generations.

Popularization and progress in areas of all-society benefits requires more long-term monitoring and search for possible ways to effectively expand the interest of the population and this kind of issue. On the one hand, according to the results there is huge interest on the given issue, on the other hand, there is also reluctance to pay the price premium for activities and products that bring added value.

Research conducted in the Czech Republic confirms that the biggest challenge in the field of CSR, BE and environmental protection through various types of certification are financial requirements and the associated increased costs, which are usually reflected in the price of certified products and services. Consumers has awareness of the individual certifications, but generally, it can be argued that when making purchase decisions, the consumers do not prefer and primarily seek products labeled with a certain certification products with added value, but in principle the most significant role in purchasing decisionmaking is price and quality.

\section{Acknowledgements}

The paper was prepared with the support of theSpecific University Research found of Faculty of Forestry and Wood Technology, Mendel University in Brno No. LDF_VP_2017003 and the National Agency for Agricultural research, Grant No. QK1820358. 


\section{References}

AUDEBRAND, L.; PAUCHANT, T. (2009). Can the Fair Trade Movement Enrich Traditional Business Ethics? An Historical Study of Its Founders in Mexico. Journal of Business Ethics [online]. 87(3), 343-353 [cit. 2018-07-26]. DOI: 10.1007/s10551-008-9924-8. ISSN 01674544. Available at: http://web.b.ebscohost.com/ehost/pdfviewer/pdfviewer?vid=4\&sid=e30d2719-7719-4d50-bf2e30b6bcc91009\%40pdc-v-sessmgr05 (accessed $26^{\text {th }}$ July 2018)

BROWN, R. (2018). Dear coffee buyer. Twenty Six Letters. ISBN-10 1532364822, ISBN-13: 9781532364822.

Čsú. (2015). Počet aktivních podnikatelských subjektů [Number of active business entities], Czech Statistical Office. (accessed $5^{\text {th }}$ May 2015). Available at: https://vdb.czso.cz/vdb/ukazatele.jsp?typ=3.

FAIR TRADE. (2010). Periodizovaný preehled hlavních událostí historie Fair Trade. [The History of Fair Trade: Periodized Overview of the Main Events of the History of Fair Trade]. Fairtrade.cz [online]. () 2010 Available at: http://www.fairtrade.cz/36-historie-fair-trade/ (accessed 10 th July 2018)

FAIR TRADE ČESKO A SLOVENSKO. [Fair Trade Czech Republic and Slovakia] (2018) Co je Fair Trade? [What is Fair Trade?] Available at: https://www.fairtrade-cesko.cz/fair-trade (accessed 20 th July 2018).

FAJMON, H.; LOUŽEK, M. (2010). Vznik EFTA: padesát let poté. [The Creation of EFTA: Fifty Years After: Anthology of Texts] Sborník textů. Praha: CEP-Centrum pro ekonomiku a politiku. [CEP-Center for Economics and Politics], Ekonomika, právo, politika. [Economics, Law, Politics] ISBN 978-80-8654791-6.

FOREST STEWARDSHIP COUNCIL (FSC). (2002). What is FSC? Available at: http://www.fscoax.org/principal.htm (accessed $4^{\text {th }}$ November 2002).

FRIDELL, G. (2007). The Prospects and Pitfalls of Market-driven Social Justice. 2007, ISBN 978-0-80209238-0.

FRIEDEL, D. (2003). Etika v podnikání [Ethics in Business]. Databáze nejlepších praktik [Database of the Best Practices] Available at: http://bestpractices.cz/seznam-praktik/ (accessed 27th July 2018)

FSC CZECH REPUBLIC. (2018). Kolik stojí šetrné hospodaření v lesích a certifikace FSC? [How Much Do the Forest Friendly Management and FSC Certification Cost?], Available at: http://www.czechfsc.cz/novinky/novinky-v-cr/kolik-stoji-setrne-hospodareni-v-lesich-a-certifikace-fsc--237.html (accessed $4^{\text {th }}$ April 2018)

HÁJEK, O.; NOVOSÁK, J.; ZAHRADNÍK, P.; BEDNÁŘ, P. (2012). Regionální disparity a financování regionální politiky [Regional Disparities and Regional Policy Funding], Political Economics 60 (3). pp. $330-348$.

IPSOS CSR \& REPUTATION RESEARCH (IPSOS). (2017). Společenská odpovědnost firem ovlivňuje lidi při jejich doporučování a rozhodování [Social Responsibility of Companies Influences People's Recommendations and Decision-Making]. Available at: https://www.ipsos.com/cs-cz/spolecenskaodpovednost-firem-ovlivnuje-lidi-pri-jejich-doporucovani-rozhodovani (accessed 22 nd March 2018).

KLEIN, P.; SLOVÁČKOVÁ, H.; MICHAL, J.; BŘEZINA, D. (2018). Fair Trade research. Available at: https://goo.gl/forms/WnNowGOByg649sOz2 (accessed $20^{\text {th }}$ July 2018)

KLOPFER, M. (1995). Etika podnikania [Business Ethics]. $1^{\text {st }}$ edition, Bratislava: Slovak Pedagogica IPublishing, 83 p. ISBN 80-0801-023-1

KOUBSKÁ, K.; HRALOVÁ, E. (2006). Společensky odpovědné podnikání jako trend a přiležitost [Socially Responsible Business as a Trend and Opportunity]; CIR, Dostupné z: http://www.cir.cz/priruckacsr/482649/1985622 (accessed $20^{\text {th }}$ December 2017). 
KPMG. (2017). Nákupní zvyklosti $v$ ČR, [Shopping habits in the Czech Republic]. Praha. Available at: https://assets.kpmg.com/content/dam/kpmg/cz/pdf/KPMG_Nakupni_zvyklosti_2017_web.pdf (accessed 23 ${ }^{\text {nd }}$ March 2018)

LANDIVAR, N. (2004). Spravedlivý obchod v České republice. [Fair trade in the Czech Republic]. In: Asociace pro Fairtrade. Fair Trade. Internal document. p.5

LAURA, T.; RAYNOLDS, H.; DOUGLAS, L.; WILKINSON, J.; WILKINSON, M. (2007). Fair Trade the challenges of transforming globalization: the prospects and pitfalls of market-driven social justice. London: Routledge. ISBN 02-039-3353-2.

LUKNIČ, A. (1994). Štvrtý rozmer podnikania [The Fourth Dimension of Business], Bratislava: Slovak Academic Press, $344 \mathrm{~s}$.

MARCOVITZ, H. (2011). Fair Trade: the prospects and pitfalls of market-driven social justice. Edina, Minn. ABDO Pub. ISBN 978-1-61714-772-2.

MICHAL, J.; SUJOVÁ, A. (2017). Perception of certified wood products by consumers in the Czech Republic; In Management and economics in manufacturing: Proceedings of scientific papers. $1^{\text {st }}$ Edit. Zvolen: Technical University in Zvolen, pp. 244-251. ISBN 978-80-228-2993-9.

NÁDVORNÍK, O.; VOLFOVÁ, A. (2004). Společný svět: příručka globálního rozvojového vzdělávání. Praha: Člověk v tísni-společnost při ČT. [People in Need - Czech Television Foundation, Public Service Company, the Common World, Fair Trade] ISBN 80-903-5100-X.

NATIONAL INFORMATION PORTAL FOR CSR. (2017). Ocenění na míru ušité malým a středním podnikům, rodinným firmám a sociálním podnikưm [Awards Tailored to Small and medium-sized Companies and Social Enterprises]. Responsible Business. Available at :http://narodniportal.cz/podnikameodpovedne-oceneni-na-miru-usite-malym-a-strednim-podnikum/ (accessed 11 th March 2018).

NEČADOVÁ, V. (2014). Etika v podnikání, Studijní opora, Vysoká škola polytechnická Jihlava, [Ethics in Business, Learning Support, The College of Polytechnics Jihlava] Jihlava, 271 p. Available at: http://www.vspj.cz/ISBN/Skripta\%20-

\%20V\%C5\%A0PJ/Etika\%20v\%20podnik\%C3\%A1n\%C3\%AD\%20-

\%20V\%C4\%9Bra\%20Ne\%C4\%8Dadov\%C3\%A1.pdf (accessed 25 th July 2018).

ŠíPKOVÁ, M.; CHOI, T. H. (2015). Business Ethics Perceptions in the Czech Republic during Global Economic Crisis, Academic Journal of Interdisciplinary Studies, Rome Italy, vol. 4. No. 1 ISSN 2281 3993 115-127

VLADYKOVÁ, L'. (2009) Morálno - filozofické implikácie netradičných ekologických vied v ekofilozofickom diskurze. [Moral-philosophical implications of Non-traditional Ecological Sciences in the Ecophilosophical discourse]. Košice: UPJŠ v Košiciach, 2009, s. 9-10

VLOSKY, R. P.; TSADEMIR, C.; GAZO, R.; CASSENS. (2015). Temporial view of U.S. value-added wood product manufacturers and certification: 2001, 2007 and 2014. Proceedings of Scientific papers. Dubrovník, Croatia. pp. 179-184

WORLD WILD LIFE FUND (WWF). (2002). Global Forest and Trade Network, Available at: http://www.panda.org/about_wwf/what_we_do/forests/what_we_do/management/gftn (accessed $24^{\text {th }}$ February 2003). 